\title{
The development of Nida's central part architecture. Prospects for development
}

\author{
Nijolè Piekienè \\ Vilnius Gediminas Technical University, Pylimo str. 26/1, Vilnius 01118, Lithuania \\ Klaipéda University, Donelaičio str. 5, Klaipéda, 92144, Lithuania
}

\begin{abstract}
Nida is the largest settlement in the Curonian Spit. The settlement's urban structure is the result of a long historical development process. Nida's urban-architectural framework has developed over hundreds of years. Year after year, the social expression and development of elements have evolved here which had an impact to today's ethno-cultural and urban development of the reserves. Ethno-cultural and urban reserves should evolve in a way that could maintain the network of roads and streets, construction sites structure, building orientation that have formed over the centuries.

This paper examines the central part of Nida historical-urban development, the buildings of the area, the protection and management options. The impact of the projected structures formed in the context of the historic buildings are analysed as well. This paper provides an overview of the circumstances on which the local folk tradition could be preserved.
\end{abstract}

Keywords: Curonian Spit; ethno-cultural; urban reserves.

\section{Nida's historical-urban evolution}

The village's structure is largely dependent on natural conditions established by the historical environment, public awareness and the level of the economic development. Nida's building structure was formed by continuous blowing of the wind, the blown sand and inner skirmishes in the community.

It is believed that the first inhabitants of the Curonian Spit, hiding from the constant winds and drifting sand, settled on parabola shaped dunes. The remains of settlements had been found on Grobstas' horn and around Nida [8]. The settlements from that time did not remain. The drifting of the sand was sped up by cutting down forests and the residents had to move from one place to another.

a)

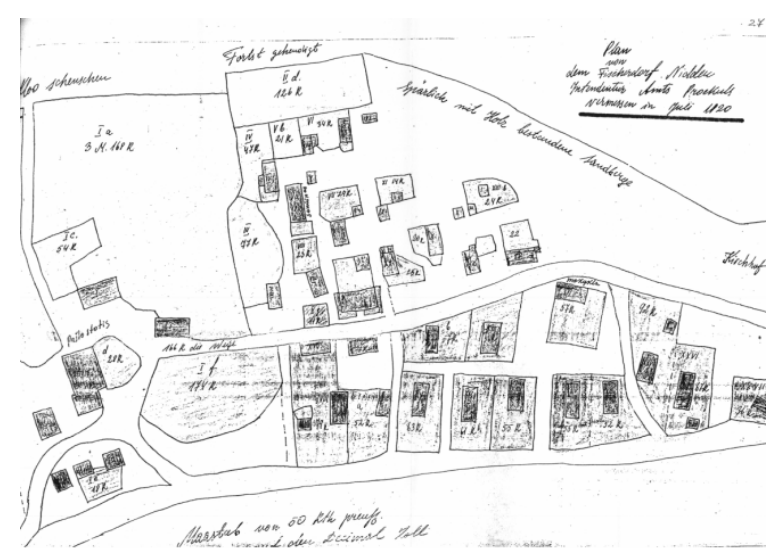

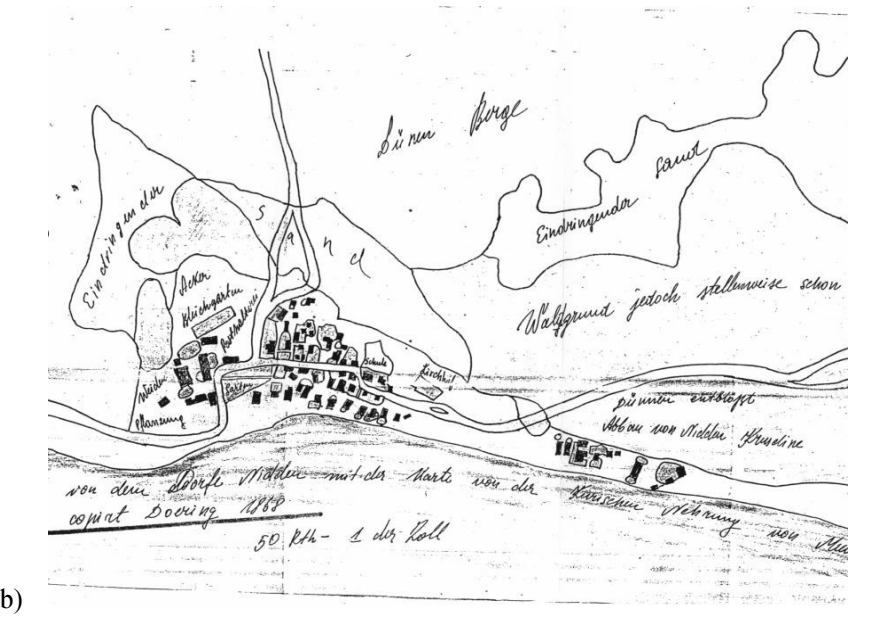

b)

Fig. 1. Nida's buildings in 1820 (a) and Nida's buildings in 1868 (b)

Corresponding author: Nijolè Piekienė. E-mail address: nijole.lin@gmail.com http://dx.doi.org/10.3846/enviro.2014.130

(C) 2014 The Author. Published by VGTU Press. This is an open-access article distributed under the terms of the Creative Commons Attribution License, which permits unrestricted use, distribution, and reproduction in any medium, provided the original author and source are credited. 
Since the beginning of the nineteenth century the settlements were created only in the Curonian Lagoon (Fig. 1a, b). Almost all of them are located in the meadow between the lagoon and the Great Dune Ridge, the south-eastern side of the dune's crest of the slope [8].

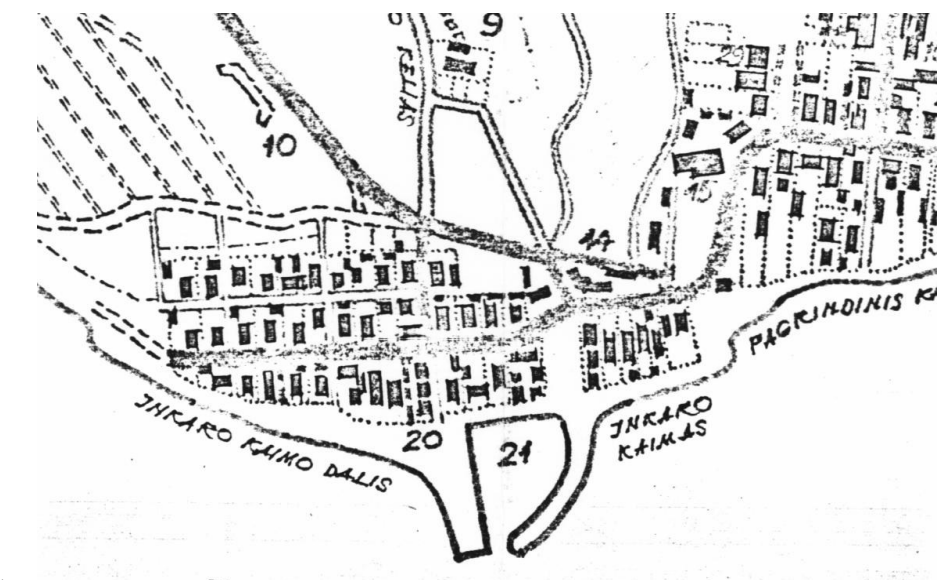

a)

b)

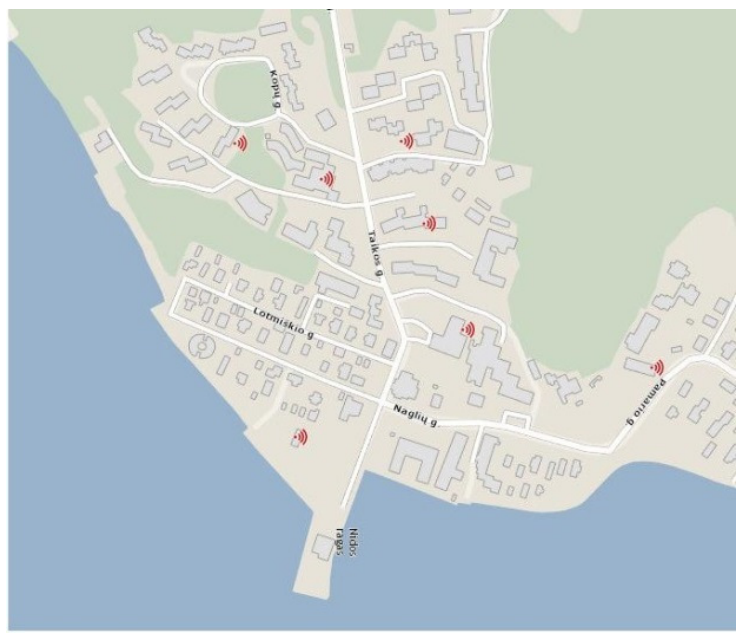

Fig. 2. Nida's buildings in 1942 (a) and Nida's buildings in 2014 (b)

Nida's central part, as indicated by J. Bucas' book, the Curonian Spit National Park, called the village of Antragis, had its own building structure and functional expression [8]. Its building and architectural nature and the intended use of ethnic architecture became a distinguished architectural building type (Fig. 3). The ethnic architecture which developed close to the lagoon, was a symmetrical single-storey fishermen's house, the rear end directed at the bay (Fig. 2a, b). An empty lot near the northern jetty used to be a fishing market. The southern part of building is also symmetrical: the fishermen's houses are located on both sides of the street (now Lotmiskis' and Naglis'). A well distinguished building by its structure in the central part of the village is the Youth House (now the Naglis' street 27) and the road to the lighthouse. Because of this can be characterized the cultural landscape's aesthetic qualities: the structure of the traditional fishermen's houses, the internal composition, the relationship with the terrain, the forested dunes as well as the older peoples' relationship with nature.

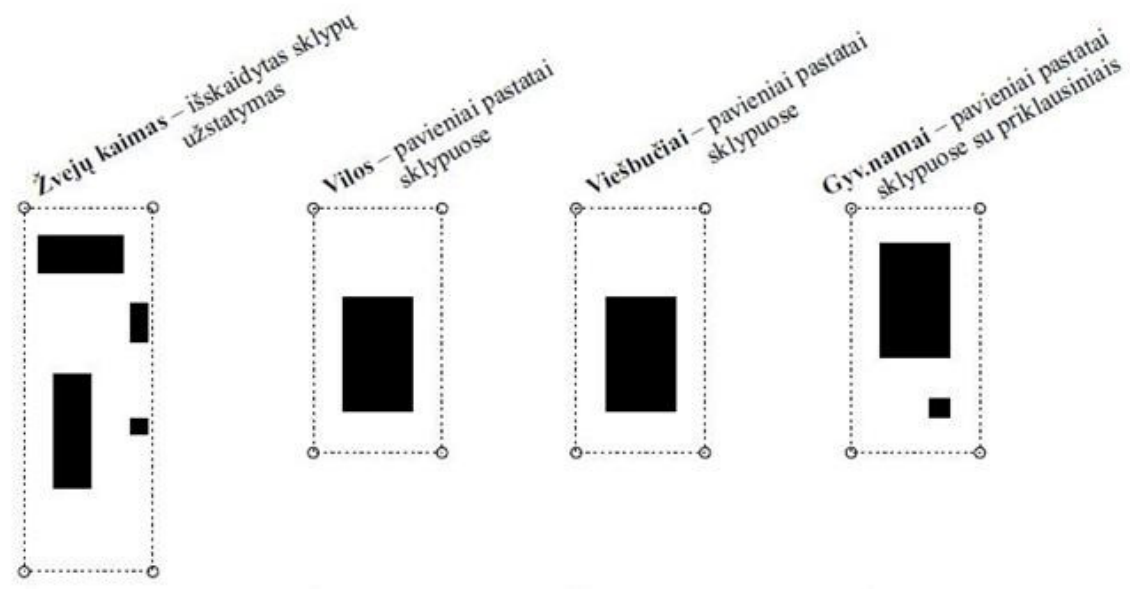

Fig. 3. Example. The various structures of the buildings in the site

The current Antragis' village is an area built-up by public and residential buildings. Antragis' ethnographic building structure was changed during the Soviet period that built the fishing port and some industrial buildings, the shopping center Kursis (Fig. 4a) and the restaurant Nida (Fig. 4b). The urban structure of the buildings stopped the tradition of compact building of the houses. The new architecture stood out with a large scale, non-traditional building traditions, materials and decorative elements. 
a)

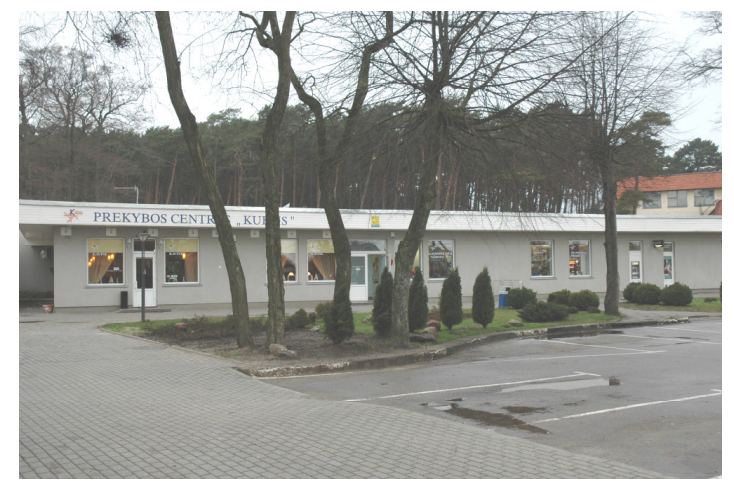

b)

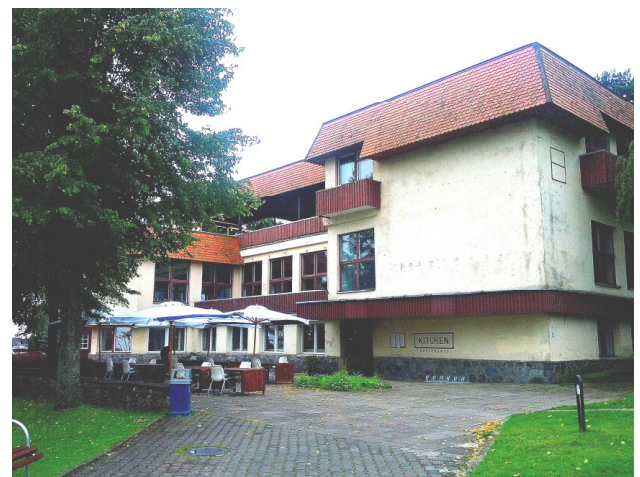

Fig. 4. Photo "Kursis" (a) Photo restaurant "Nida" (b)

In the façades of grey Soviet buildings the Neringa municipality building is brought out, see Fig. 5. This is the architect's Alfredas Gytis Tiskus' created monument, designed in around 1970-1975, it's a relatively large building in volume, split into vertical volumes, and playful pediments. The image finished with red clay tiles. Stylized wind boards, weathervanes, wooden decoration motifs - the architectural details typical of the Curonian architecture. However, this is a new, modern building, Neringa city autonomy's symbol [9].

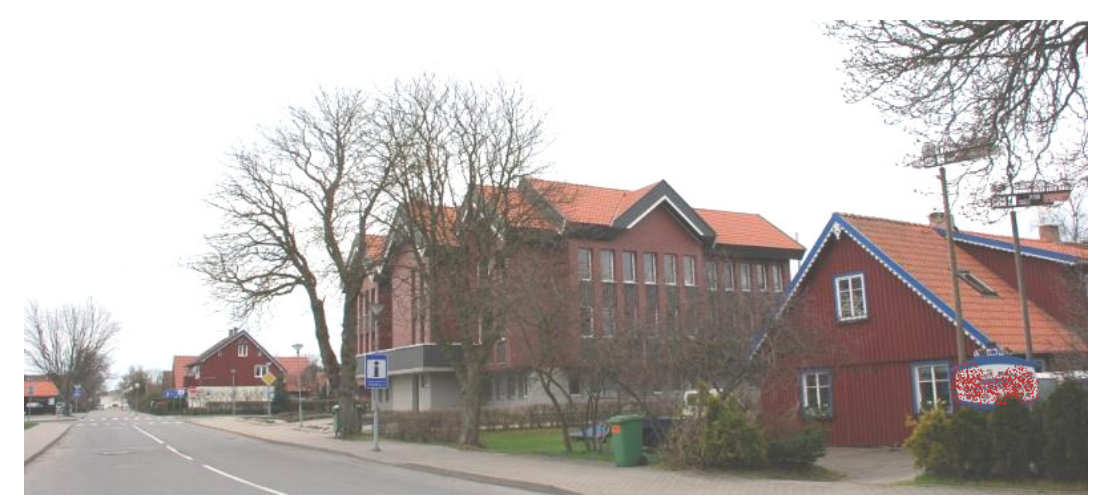

Fig. 5. Neringa municipality building

After the reconstruction of the building facades the colour was also renewed, the facade is equipped with an elevator. This is an example of the new architecture where the architectural traditions were continued.

According to specialists, the new i.e. modern architecture's intervention has to and, inevitably, will be with the historic environment, which will shape new spaces, buildings, restorations, alterations [10]. Architects, urban planners, and planners often disagree on the developmental prospects which should form the central part of the village, located outside the reserves. This area in the documents of spatial planning is identified as a newly built or substantially transformed the old building area in the Soviet period. The mostly unchanged old-historical (pre-Soviet) building area is designed to store and display the Curonian Spit's architectural heritage, reveal its unique relationship with the surrounding landscape and to investigate the peculiarities of the relationship between the landscape, cultural and natural landscape and human interactions [11]. The most important of these interactions' support measures are the newly formed or established environmental laws of ethno-cultural heritage, limiting the potential negative impact on the protected elements and the entire cultural landscape.

\section{The development buildings in the territory and building architecture in the background of Urban Reserve}

In Nida, and Lithuania as a whole, urban planning processes of the residential areas are taking place. Not always these processes go as planned in the General Plans, which state that one of the objectives of the development of the territory is to optimize the system for urban landscape and biodiversity, cultural heritage, production and use of the recreational areas and the socio-cultural and technical infrastructure territorial development [13]. Many cities and towns are faced with territorial development planning and design challenges: land configuration, the lack of public spaces, the invasion of the modern architecture to the historic environment, and so on.

In the late twentieth century postmodernist architects were convinced that the new building should be sensitive to the cultural traditions of balanced context. The search for the architecture's spirit and connection to a specific location is related to the 'genius loci' concept which guide architects in their pursuit of the obvious and latent, but the ever deep connection between the projected object and the specific facts of life [6]. The main goals of contemporary architecture in the historic urban landscape analyses the World Heritage Committee. The Vienna's memorandum contains a provision that it is necessary to pay attention to the dynamics of territorial development, promoting social and economic development and growth but at the same time respecting the inherited townscape and its landscape setting. [14]. Nida's central buildings 
should be reconstructed, rebuilt, renewed and so on, however, with what architectural, urban means and details? The new architectures that alter the structure of the pre-established urban and architectural form are inevitable, but most importantly, the UNESCO protected area should be used not only for traditional, but also modern means of expression, they must be adapted to local conditions and circumstances, at the same time improving the quality of life.

A perfect example can be the soon to be renovated Cultural Centre "Agila" (Fig. 6a, b) which was built in the twentieth century in the center of Nida, which is dominated by real objects of cultural heritage, administrative, commercial, recreational buildings, and public spaces.
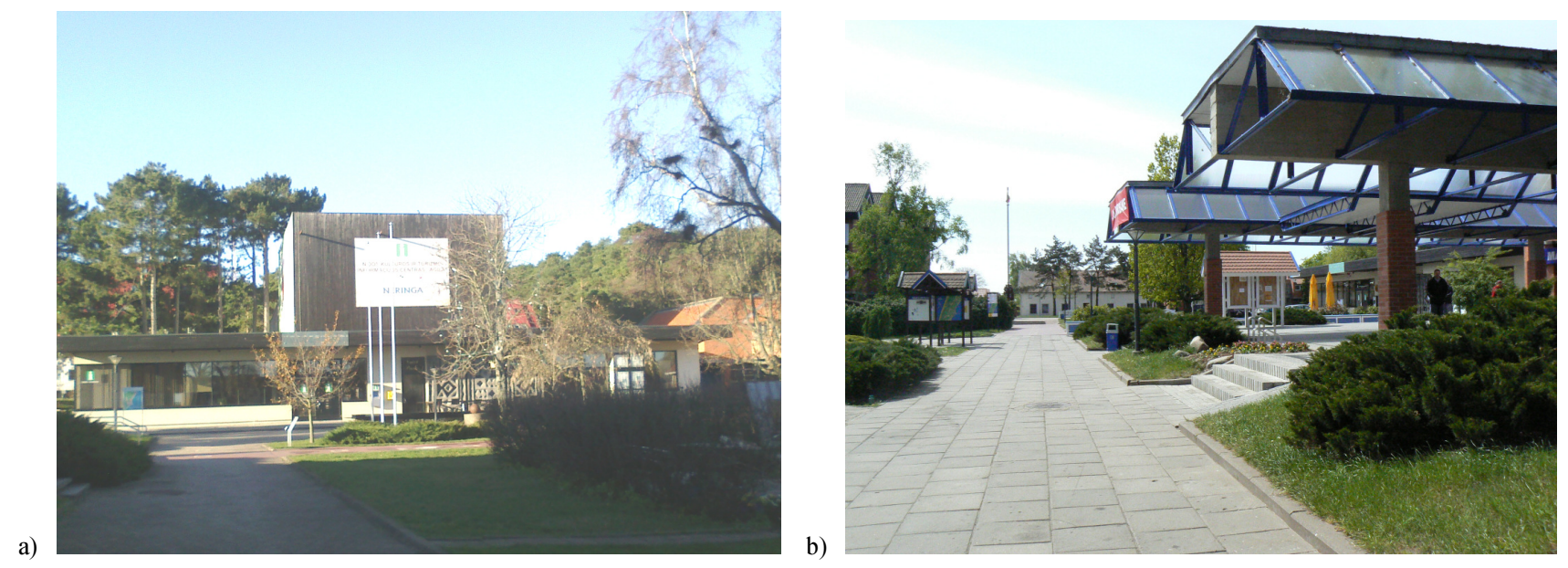

Fig. 6. Cultural Centre "Agila" (a) and En route to "Agila" (b)

As stated in the guidelines for the competition for the Cultural Center "Agila" architectural concept, the building must integrate harmoniously into the central part of the city, and to adapt with the character of the city's scale. The idea of architectural uniqueness should come into light by adding a touch of modern and contemporary architecture: spatial solutions, organic relationship with the urban environment and also the natural elements as a whole [15].

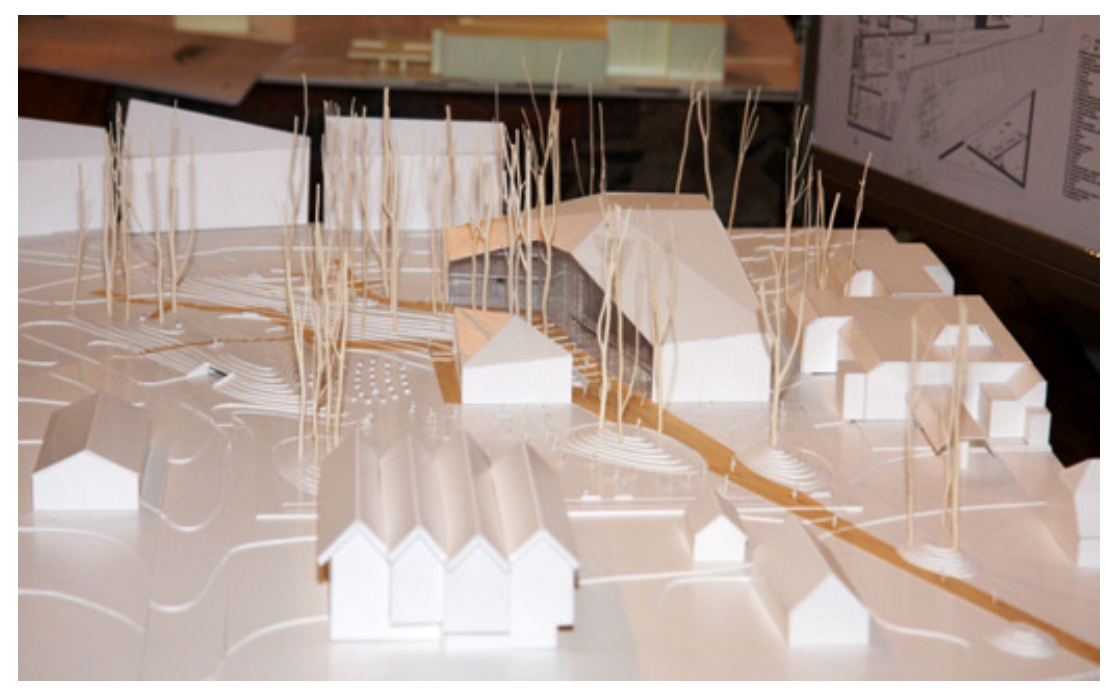

Fig. 7. Nida Culture and Tourism Information Center "Agila" architectural concept competition's 1st place

Today the Nida landscape is perceived as a settlement with natural and cultural values of the Curonian Spit. The most striking element of the landscape are the red tiled double-sloped roofs amidst the forested dunes. The Culture Centre's planning solution foresees a large building occupied area, glass facades, and zig-zag-shaped roofs (Fig. 7, 8). However, the scale, the relationship with the context, and the organic link with the urban environment and the entirety of the natural elements are important points in the concept's guidelines. It is obvious that the current (upcoming) urban-architectural changes affect the representativeness of the area, the architectural tradition and the nurturing of other Neringa's settlements' trends and will have an effect on the UNESCO list. 

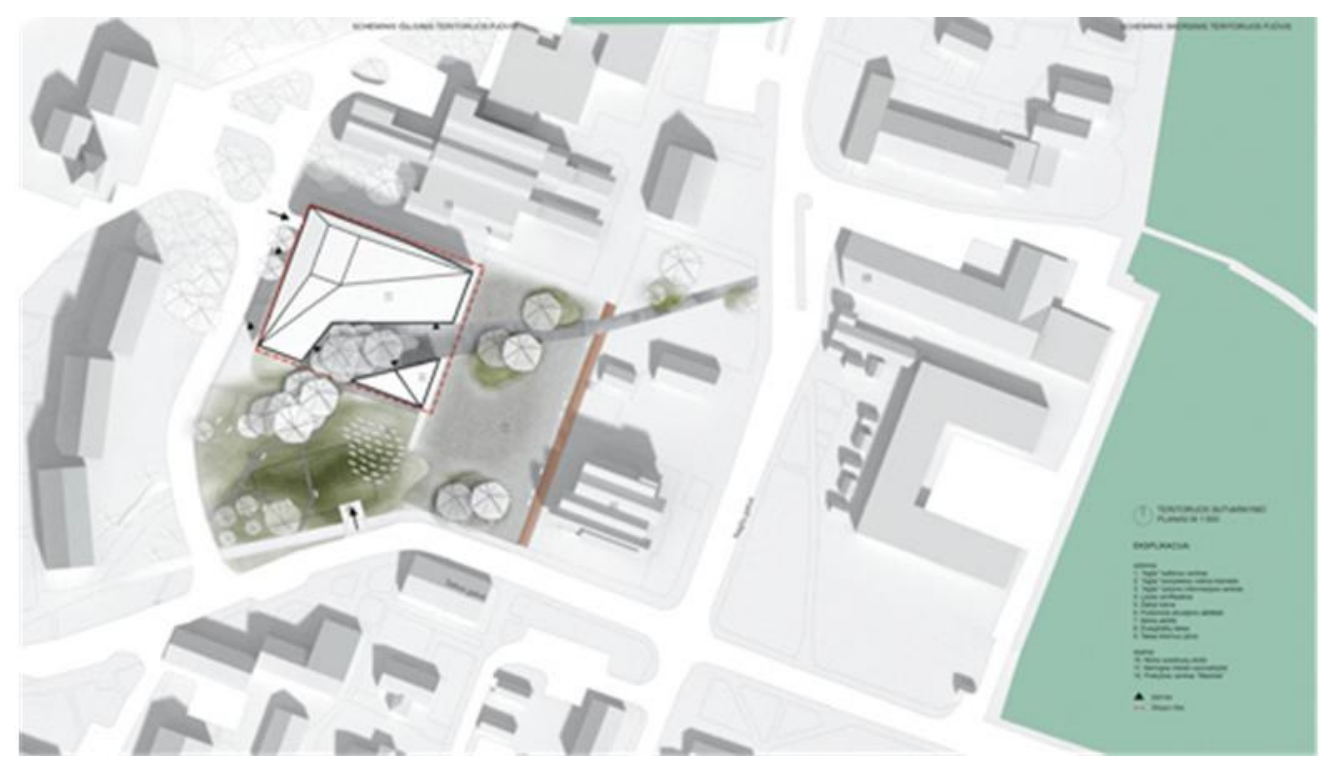

Fig. 8. Planning solution. The growth of building forms an aggressive urban environment

The development of Nida's central part's architectural traditions or forming of the cities (settlements) is not only a problem of the general structure of the urban village's center, but also some of its parts - the waterfront, plaza, squares, and even some of the buildings or groups of buildings. Contemporary architecture is a significant intervention in the already established historical surroundings, including the open spaces, new buildings, annexes to historic buildings and sites. Undoubtedly, the creative source for architects usually serves a pre-formed architectural context, culture, traditions (informal factors), but the mutual actions of professionals and the general public, and the daily practical use of spaces can be an inspiration for the creation of a distinctive and safe environment [1]. There is no doubt regarding the participation of the public in the presentation of the prepared projects. The presentation to the general public of the project plans, templates, models and visualizations on the Internet provides much more information that could be obtained and analysed at any time, stored and protected the materials as well as to give their opinions and suggestions [7].

\section{The planning of public spaces by sustainable development principles}

To a town or a city a particular building or its architecture are not of much interest as its volume, the public space formed around it, and the influence to the panorama of the settlement. The city is a living organism, people live not only in their homes, but also walk the pedestrian and bicycle paths, meet, chat, admire or rest in plazas, squares. One of the key principles of the modern urban planning is to first plan out the public spaces. They must be suitable for the urban structure and the environment [16].

Unfortunately, the planning of public spaces is not always associated with vacant land (reserved for public purposes or the like). The needs of territorial and functional development have fallen victim to a primitive economic factor - the desire to sell the land for practical and residential construction. This development method is not effective. There are no areas left for the general use of greenery, recreational areas, public spaces and service development [3].
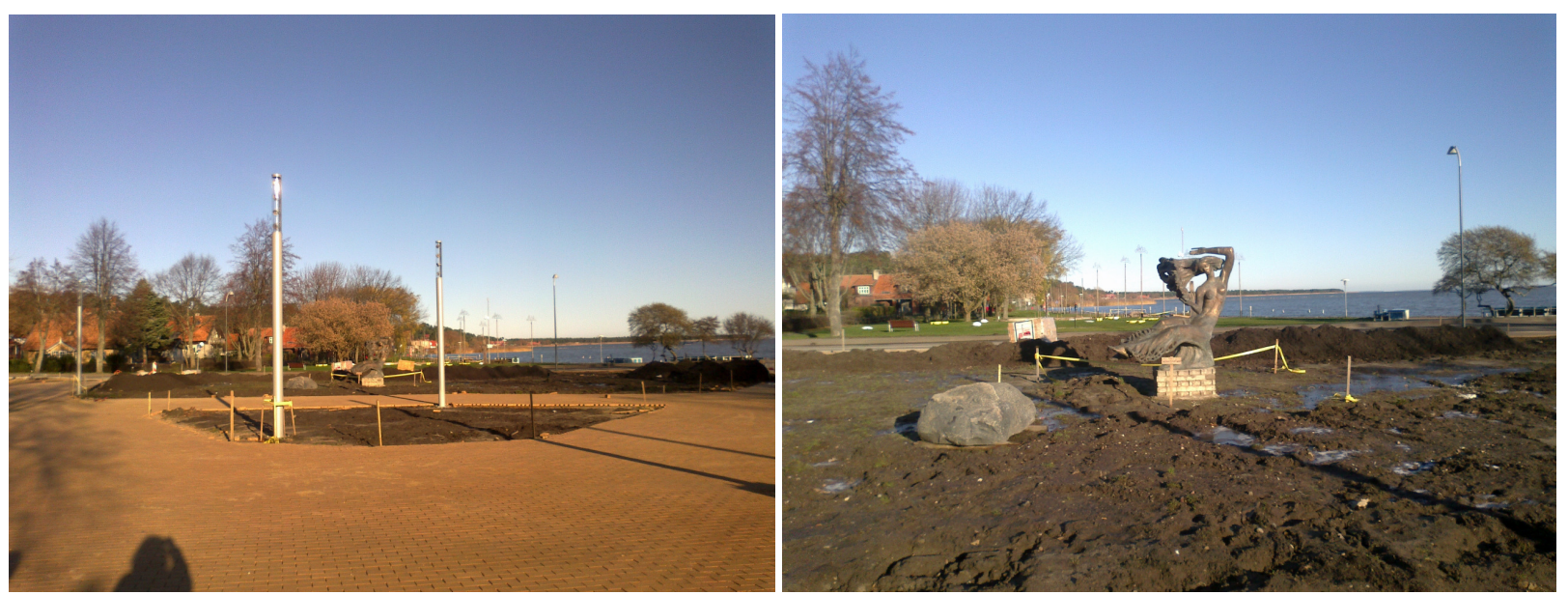

Fig. 9. The reformation of the public space in Nida centre $(a, b)$ 
The public space of Nida's central part is reconstructed according to a prepared project. The design of new pedestrian paths, equipped with modern lightings and sculptures are also included (Fig. 9a, b). According to specialists, the modernization of public spaces does not return the townspeople. Places, like people, have or do not have their own charisma, so not everything is determined by the planners' ideas. Sometimes the square or plazas are left unattractive to people [5]. Another common mistake is cutting the greenery, forgetting the freedom to choose where to sit - in a sunny spot or in the shade - which promote staying in public spaces for a longer period of time. The reconstructions of the public spaces surprisingly have a common conservative approach to static monuments as the only possible form of commemoration for historical events. Clumsy monuments are nothing more than a killing instrument of live memory [4].

While designing and installing sidewalks in Nida, the greatest attention should be paid to the paths so that residents and visitors would be able to make contact with the historical, cultural, commercial, and residential buildings.

Pedestrian street is in dire need of appropriate conditions for living, working, shopping, entertainment, recreation, communication and all other needs. Moreover, the creation of the environment for such streets depends on street architecture, the features of historical and cultural heritage and space size [2].

\section{Conclusions}

Nida as well as all of the Curonian Spit is a complex protected area of exceptional value of cultural and natural heritage where building interventions that may potentially violate this territory's natural properties of cultural and natural value, strictly regulated by UNESCO, and the European and Lithuanian legislations.

Nida central part's architectural and urban activities are carried out, regardless of the already existing building traditions, the relationships with the urban environment, the entirety of natural elements, all will inevitably affect the visual quality of the protected area.

\section{References}

[1] Jakaitis, J.; Bielinskas, V. 2013. Saugumas viešosiose erdvėse kaip demokratinių miestų planavimo principų taikymo rezultatas (Vilniaus miesto pavyzdžiu). The Security in Public Spaces as the Result of Applying the Principles of Planning in Democratic Urban Cities (the example being the city of Vilnius), in Lietuvos Kraštovaizdžio architektūros forumo 2013 m. mokslo darbai, pg. 111-120.

[2] Jakovlevas-Mateckis, K. 2013/4. Miestų pésčiujų gatvių ir zonų formavimo tradicijos. The Formation Traditions of Pedestrian streets and zones, Journal Construction and Architecture, 50-53.

[3] Grecevičius, P.; Abromas, J.; Rimkus, A. 2012. Vakarų Lietuvos miestelių gyvybingumo palaikymo urbanistinių priemonių kompleksas. Maintaining the vitality of the urban set of measures of the towns in Lithuania's west, Journal VI Lithuania's urbanistic forum, 33-37.

[4] Lavrinec, J. 2013.Viešujų erdvių potencialas. The Potential of Public Spaces, Journal Construction and Architecture, 46-48.

[5] Lukšytė, I. 2013. Kur rinksimès. Where We'll Gather, Journal Construction and Architecture, 34-35.

[6] Buivydas, R. 1999/3. XXa. Architektūra: regionalizmas. The Architecture of the Twentieth Century: Regionalism, Journal Archiforma, 70-77.

[7] Stauskis, G. 2013. Virtualios realybès metodų taikymas kuriant ir vertinant kraštovaizdžio architektūrą. Application of Techniques of Virtual Reality for Assessing the Development of the Landscape's Architecture, Journal,Forum Lithuania's Landscape's architecture 2013 m. science works, 100110 .

[8] Bučas, J. 2001. Kuršiu nerijos nacionalinis parkas. Curonian Spit National Park. Vilnius. pg. 53-103.

[9] Demereckas, K.; Ramanauskienè, M.; Januševičius, J. A.; Baltrūnè, G.; Adomaitis, R. 2011. Traditional architecture of the Curonian Spit. Studies and rekomendations for the landlords and builders. Klaipèda.

[10] Navickienè, E. 2006. Nauja architektūra istorineje aplinkoje. The New Architecture in the Historic Environment. Vilnius: Technology.

[11] Neringa municipality territories and its parts in the General Plan. Approved in September 21st 2012

[12] Neringa Municipality's Board decision No. T1-164.

[13] State General Plan, State News, 2002, No. 110-4852.

[14] Vienna memorandum. Approved $2005 \mathrm{~m}$. World Heritage Committee $29^{\text {th }}$ session.

[15] Nida's Culture and Tourism Informational Centre „Agila“ architectural conception open simplified project's competition's guidelines. Approved by Neringa municipality administrator in December $20^{\text {th }} 2011$ regulation No. V13-576.

[16] Vilnia's Coast Is Awakening for a New Life. Journal of Construction and Architecture [online]. Available from Internet: www.sa.lt [cited 12 January $2014]$. 